\title{
THE DEVELOPMENT OF CREATIVE AND PEDAGOGICAL ASPECTS IN THE PROCESS OF MEDICAL STUDENTS TRAINING
}

\section{РОЗВИТОК ТВОРЧО-ПЕДАГОГІЧНОГО АСПЕКТУ У ПРОЦЕСІ НАВЧАННЯ СТУДЕНТІВ-МЕДИКІВ}

\section{Kichula Maria ${ }^{1}$ \\ Savaryn Tetyana ${ }^{2}$}

DOI: http://dx.doi.org/10.30525/978-9934-571-27-5_20

\begin{abstract}
The purpose of the research is to create and implement the pedagogical conditions that promote the formation of the professional skills of future physicians through the lens of the creative and pedagogical aspect. Methodology. During the experiment, the following methods were used: theoretical analysis of diagnostic; observational; the method of statistical manipulation. Students of medical and dentistry faculties of the I. Horbachevsky Ternopil State Medical University took part in experiment, totally more than 500 respondents. The control and the experimental groups were established at the beginning of experiment. The traditional approach to teaching medical students was practiced in the control group; an approach to modernizing the educational process at the medical university that is based on the creative-pedagogical aspect was introduced in the experimental group. Performance criteria. Data of three diagnostic sections - primary, secondary and final are taken into account for diagnosing the ascending level and the dynamics of creativity and professional readiness of students. The effectiveness of the methodical process of forming a model of creative orientation training was showed by sections. The results of experimental work showed that the most important implementer of the creative and pedagogical aspect in the training formation and development of medical students is the individualization of the educational process based
\end{abstract}

\footnotetext{
${ }^{1}$ Candidate of Pedagogical Sciences,

Assistant Professor at Department of Foreign Languages,

I. Horbachevsky Ternopil State Medical University, Ukraine

${ }^{2}$ Candidate of Philological Sciences,

Assistant Professor at Department of Foreign Languages,

I. Horbachevsky Ternopil State Medical University, Ukraine
} 
on the results of diagnostic sections, individual testing for planning the content of all types of creativity, cognitive and creative and practical work of future medical specialists.

\section{1. Ветуп}

Сучасний процес підготовки дипломованого спеціаліста-медика ставить нові вимоги до організації навчання в медичному вузі, оскільки у суспільстві все більше зростає необхідність розвитку творчого потенціалу особистості майбутнього лікаря. Творча діяльність породжує нові знання, навички, вміння і відношення. Сучасна освіта позиціонує студента не як пасивного одержувача знань, а як активного учасника навчального процесу. Особливу увагу у вищій медичній школі приділяють розвитку розумових здібностей студентів. Це веде до появи постійно нових поглядів на творчий процес, що сприяє створенню нових підходів до поняття творчість у навчальному процесі. Мета дослідження полягає в тому, щоб створити та реалізувати педагогічні умови, які сприяють формуванню професійних якостей майбутніх лікарів крізь призму творчо-педагогічного аспекту. Припускаємо, що впровадження творчо-педагогічного аспекту в навчальний процес студентів-медиків буде ефективним, якщо його реалізація сприятиме професійному особистості майбутнього лікаря шляхом розвитку інтелектуального, освітнього, етичного творчого потенціалу студентів-медиків.

\section{2. Педагогічні умови формування творчо-професійної готовності}

Процес збагачення професійної наукової діяльності студентів медичного вузу креативною спрямованістю вимагає комплексу науково-педагогічних розробок, які сприяють розвитку креативності студентів-медиків. Творчо-професійна готовність як системний і цілісний об'єкт являє собою органічну єдність і інтеграцію різних видів професійної діяльності студентів-медиків у процес оволодіння майбутньою спеціальністю, що забезпечують формування компонентів творчо-професійної підготовки. Система професійно-творчих якостей студента-медика побудована на сукупності професійно-особистісних властивостей, які безпосередньо впливають на всі перераховані види творчо-професійної готовності. Особистісні якості студента-медика, не маючи прямого впливу на результати креативної активності майбутнього лікаря, здатні відіграти значну роль у розгортанні його творчого 
потенціалу, у формуванні його професійно-творчого мислення. Щоб сформувати у студентів-медиків бажані креативні якості, залучено студентів до спеціально організованої професійної діяльності з урахуванням творчо-педагогічного аспекту.

Доцільним є виокремити наступні основні творчі якості студента медичного вузу з урахуванням творчо-педагогічного аспекту, які вимагають подальшого розвитку, сприяючи формуванню творчо-професійної готовності:

- творче усвідомлене ставлення до індивідуальної креативної діяльності як необхідності зміни медико-професійної дійсності;

- творче формування самим студентом-медиком індивідуального особистісного модусу, що охоплює в себе творчо-професійні потреби студента, його інтереси, переконання, творчо-оцінні критерії, творчо-пізнавальні прагнення;

- творче індивідуальне прагнення студента медичного вузу до розширення і поглиблення професійних знань, до опанування нових творчо-професійних знань;

- прагнення до теоретичної та практичної обгрунтованості індивідуальних професійно-творчих поглядів і переконань.

Становлення і розвиток перерахованих творчих якостей студента медичного вузу $є$ необхідною умовою для формування творчо-педагогічного аспекту в освітньому процесі медичного вузу як результату такої готовності. Таким чином, основним завданням нашої дослідно-експериментальної роботи є розробити методику з розвитку творчих здібностей у студентів медичного вузу, яка містить в себе:

- виявлення оптимальних шляхів і засобів реалізації методології творчо-педагогічного аспекту в освітньому процесі медичного вузу;

- опис і практичну апробацію процесу формування творчих якостей у студентів-медиків;

- визначення особливостей творчо-педагогічного аспекту у вирішенні науково-дослідних завдань студентів-медиків;

- визначення теоретико-методологічної бази формування творчої спрямованості освітнього процесу у вищій медичній школі.

Для реалізації перерахованих вище завдань дослідно-експериментальної роботи в ДВНЗ «Тернопільський державний медичний університет ім. І. Я. Горбачевського МОЗ України» ми розробили програму, розраховану на кілька років упровадження. Її метою було - підготу- 
вати методичну модель процесу формування творчої спрямованості в становленні і розвитку освіти студента-медика відповідно до розробленого і теоретично обгрунтованого нами підходу до модернізації освітнього процесу у вищій медичній школі з урахуванням творчо-педагогічного аспекту.

Під час реалізації цієї програми ми здійснили адаптацію програм 3 курсу латинської мови та медичної термінології в системі творчо-педагогічного аспекту.

В експерименті брали участь студентські групи медичного (спеціальність 222 «Медицина») та стоматологічного (спеціальність 221 «Стоматологія») факультетів. На початку нашого експерименту ми визначили контрольну і експериментальну групи. У контрольній групі практикувався традиційний підхід до навчання студентів-медиків; в експериментальній групі був впроваджений запропонований нами підхід до модернізації освітнього процесу в медичному вузі з урахуванням творчо-педагогічного аспекту.

\section{3. Методи та структура експерименту}

При проведенні експерименту ми користувалися наступними методами: теоретичного аналізу (порівняльно-зіставний); діагностичними (тестування, анкетування, письмова інтерпретація ситуацій творчо-пізнавальної та професійно-практичної діяльності); обсерваційними (пряме, непряме і включене спостереження); праксиметричними (аналіз продуктів креативної діяльності студентів; вивчення і узагальнення професійної креативної діяльності); методом статистичної обробки отриманих даних.

Наша дослідно-експериментальна робота здійснювалась у кілька етапів як на рівні загального вдосконалення освітнього процесу з урахуванням творчо-педагогічного аспекту, так і на рівні індивідуальної творчо-педагогічної роботи зі студентами-медиками - типовими представниками різних рівнів готовності до професійно-креативної діяльності в галузі медичної термінології.

Виділивши етапи процесу формування творчого інтересу у студентів-медиків до медичної термінології, ми спробували визначити шляхи вдосконалення цього процесу.

В експериментальній роботі ми проводили початковий зріз рівня розвитку творчого інтересу студентів до сфери медичної термінології за наступними показниками: пізнавальний, емоційний і вольовий. 
Крім цих якісних показників, ми виділили і кількісні показники шляхом інтерв'ювання та анкетування студентів медичного та стоматологічного факультетів: як часто студенти виявляють інтерес до значення і походження медичних термінів, якими вони оперують на заняттях з спеціально-наукових медичних дисциплін; чи користуються студенти-медики додатковою спеціальною термінологічною літературою; чи знайомі вони з сучасними досягненнями в галузі спеціальної медичної термінології.

Відповідно до отриманих у результаті першого діагностичного зрізу даних на початку експерименту ми визначили за цими критеріями і показниками три рівні розвитку творчого інтересу студентів-медиків до медичної термінології в експериментальній і контрольній групах, які свідчать про творчо-професійну готовність цих студентів.

У дослідженнях брали участь студенти 1 курсу медичного і стоматологічного факультетів - понад 500 осіб, у тому числі 392 студенти спеціальності 222 «Медицина» та 112 студентів спеціальності 221 «Стоматологія».

В експериментальній групі було всього 250 осіб, 3 них: 3 високим рівнем - 37 осіб; із середнім - 93 особи; з низьким - 120 осіб.

У контрольній групі - всього 250 осіб, з них: 3 високим - 32 особи; із середнім - 96 осіб; з низьким - 122 особи.

Отримані показники творчо-професійної готовності студентів-медиків в експериментальній і контрольній групах на початковому етапі нашої дослідно-експериментальної роботи ми представили в таблиці 1.

\section{Таблиця 1}

Показники творчо-професійної готовності студентів-медиків в експериментальній групі (ЕГ) і в контрольній групі (КГ) на початковому етапі дослідно-експериментальної роботи (\%)

\begin{tabular}{|c|c|c|c|c|}
\hline $\begin{array}{l}\text { Рівні розвитку творчого інтересу, що свідчить про } \\
\text { творчо-професійну готовність студентів-медиків }\end{array}$ & $\mathbf{K} \Gamma$ & & & \\
\hline високий рівень розвитку творчого інтересу & 3 & 21 & 2 & 14 \\
\hline середній рівень розвитку творчого інтересу & 4 & 29 & 4 & 29 \\
\hline низький рівень розвитку творчого інтересу & 7 & 50 & 8 & 57 \\
\hline
\end{tabular}


Діагностика рівнів творчо-професійної готовності при проведенні формуючого експерименту показала іiі низький рівень у студентів-медиків в експериментальній і в контрольній групах.

В експериментальній групі початок дослідної роботи був пов'язаний зі спеціальною програмою - визначено новий підхід до розуміння цілей і завдань залучення студентів-медиків до дослідження певної ділянки наукової медичної термінології з урахуванням творчо-педагогічного аспекту.

Насамперед в експериментальній групі ми запропонували спеціально організовані заняття тренінгового характеру. Основною метою цих занять було активне творчо-педагогічне навчання, або творчо-педагогічний тренінг, який забезпечує подолання «креативної скутості» студентами-медиками експериментальної групи, i, як результат цього подолання, розвиток навичок для подальшої високої активності студентів в практичному розвитку власної індивідуальної креативності та розкриття власного творчого інтересу до галузі наукової медичної термінології. Крім того, у процесі тренінгових занять були також досягнуті і супутні цілі: розвиток початкової творчо-пізнавальної позиції, уміння визначати ділянку своїх творчих досліджень; здатність планувати свої творчо-пізнавальні дії; підвищення морального критерію культуротворчості як істотного компонента повноцінного професійного розвитку особистості майбутнього лікаря. Таким чином, заняття тренінгового характеру в кілька етапів, показаних в таблиці 2.

Таблиця 2

\section{Етапи реалізації занять тренінгового характеру в експериментальній групі з розвитку творчого інтересу студентів-медиків}

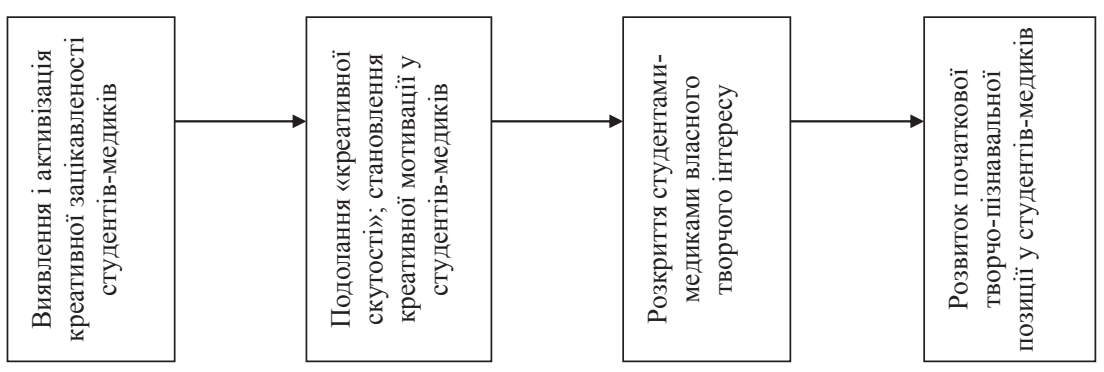


Опираючись на отримані результати, ми змінили освітній процес в експериментальній групі з урахуванням творчо-педагогічного аспекту. Це виражалося:

- у введенні, додатково до програмних занять, інтегрованих і позанавчальних заходів, що сприяють розвитку і розширенню творчого інтересу студентів-медиків; а також формуванню креативної особистості студента-майбутнього лікаря, який усвідомлює необхідність креативної діяльності в обраній медичній термінології;

- у проведенні творчих занять з медичної термінології, на яких студенти експериментальної групи представляли цікаву для них ділянку медичної термінології, що сприяло подоланню «креативної скутості»;

- у впровадженні позанавчальних додаткових занять 3 цікавої для кожного студента галузі медичної термінології, що сприяло індивідуалізації творчо-освітнього процесу, адаптації студента-медика до самостійного творчо-професійного дослідження, що в кінцевому підсумку сприяло розкриттю і реалізації власного творчого інтересу;

- у проведенні науково-практичних семінарів з медичної термінології, на яких студенти-медики експериментальної групи представляли результати індивідуальних творчих досліджень в галузі медичної термінології своїм колегам для обговорення, що сприяло формуванню і закріпленню індивідуальної чіткої творчо-пізнавальної позиції кожного студента в дослідженні медичної термінології.

\section{4. Основні етапи експерименту}

Таким чином, наша дослідно-експериментальна програма зі становлення і розвитку творчо-педагогічного аспекту в студентів-медиків містила три етапи.

На першому етапі було здійснено залучення студентів до певної ділянки наукової медичної термінології, що полягало в поглибленні уявлень студентів про дисципліни, які вивчаються, знайомство студентів із новітніми творчими досягненнями та розвитку творчих зацікавлень студентів експериментальної групи в даній галузі. Нами була здійснена активізація мотивації студентів до наукових досліджень при становленні у них усвідомленої необхідності творчих досліджень у галузі наукової медичної термінології.

Для досягнення поставлених цілей на першому етапі були проведені наступні заходи: введення курсу додаткових лекцій, які сприяють деталь- 
ному ознайомленню студентів із сферою наукової медичної термінології; введення, додатково до програмних занять, інтегрованих і позанавчальних заходів, які сприяють розвитку і розширенню творчого інтересу студентів-медиків у ділянці наукової медичної термінології; проведення творчих занять із медичної термінології, на яких студенти експериментальної групи представляли цікаву для них галузь медичної термінології.

На першому етапі були сформовані наступні креативно-особистісні якості: висока професійна грамотність у ділянці наукової медичної термінології; прагнення до вивчення новітніх творчих досягнень у галузі наукової медичної термінології; здатність до аналізу новітніх творчих досягнень; здатність до виявлення протиріч.

На другому етапі нашої дослідно-експериментальної роботи були реалізовані наступні цілі: розкриття творчого інтересу студентів-медиків шляхом подолання їх «творчої скутості»; індивідуалізація творчо-професійної діяльності студентів у цікавій для них галузі, що сприяло формуванню у студентів експериментальної групи чіткої індивідуальної творчо-пізнавальної позиції в дослідженні ділянки медичної термінології.

У зв'язку з поставленими цілями на другому етапі було здійснено впровадження позанавчальних додаткових занять з цікавої для кожного студента галузі медичної термінології, що сприяло індивідуалізації творчо-освітнього процесу, адаптації студента-медика до самостійного творчо-професійного дослідження, що в кінцевому підсумку сприяло розкриттю і реалізації власного творчого інтересу. Студентам була надана можливість самостійної творчої розробки явищ наукової медичної термінології; проведення науково-практичних семінарів 3 медичної термінології, на яких студенти-медики експериментальної групи представляли результати індивідуальних творчих досліджень у галузі медичної термінології своїм колегам для обговорення, що сприяло формуванню і закріпленню індивідуальної чіткої творчо-пізнавальної позиції кожного студента в дослідженні медичної термінології, також груповій перевірці істинності творчих суджень і розробок.

Другий етап був спрямований на формування наступних творчо-особистісних якостей: здатність до творчої розробки виявленого протиріччя; твердість, підприємливість у реалізації творчих рішень; прагнення до істинності творчого судження.

Третій етап нашої дослідно-експериментальної роботи був присвячений розвитку у студентів-медиків експериментальної групи почат- 
кової творчо-професійної позиції, який здійснювався в процесі індивідуального самостійного наукового творчого пошуку студента-суб'єкта творчості; при аналізі особистих творчих результатів, доопрацюванні деталей, наполегливому творчому пошуку найбільш раціональних способів вирішення творчих завдань.

На даному етапі відбувається становлення таких творчо-особистісних якостей, як вміння аналізувати особисті творчі досягнення, доопрацювати деталі, творча гнучкість як здатність переходити від одного аспекту завдання до іншого, від однієї гіпотези до більш досконалої. Хід нашої дослідно-експериментальної роботи представлений у таблиці 3.

Таблиця 3

\begin{tabular}{|c|c|c|c|}
\hline $\begin{array}{c}\text { Етап } \\
\text { дослідно- } \\
\text { експери- } \\
\text { ментальної } \\
\text { роботи }\end{array}$ & $\begin{array}{c}\text { Цілі реалізації } \\
\text { експерименту на } \\
\text { даному етапі роботи }\end{array}$ & $\begin{array}{c}\text { Проведені заходи в ЕГ } \\
\text { студентом-медиком }\end{array}$ & $\begin{array}{c}\text { Творчо-особистісні } \\
\text { якості, розвинені у } \\
\text { студентів-медиків } \\
\text { ЕГ на даному етапі }\end{array}$ \\
\hline 1 & 2 & 3 & 4 \\
\hline I & $\begin{array}{l}\text { - залучення студен- } \\
\text { тів до галузі наукової } \\
\text { медичної терміно- } \\
\text { логії; } \\
\text { - активізація моти- } \\
\text { вації студентів до } \\
\text { наукових досліджень } \\
\text { при становленні у } \\
\text { них усвідомленої } \\
\text { необхідності творчих } \\
\text { досліджень в галузі } \\
\text { наукової медичної } \\
\text { термінології }\end{array}$ & $\begin{array}{l}\text { - запровадження курсу } \\
\text { додаткових лекцій; } \\
\text { - введення інтегрова- } \\
\text { них і позанавчальних } \\
\text { заходів; } \\
\text { - проведення творчих } \\
\text { занять з медичної тер- } \\
\text { мінології }\end{array}$ & $\begin{array}{l}\text { - висока професійна } \\
\text { грамотність у дослі- } \\
\text { джуваній галузі; } \\
\text { - прагнення до } \\
\text { вивчення новітніх } \\
\text { творчих досягнень в } \\
\text { цій галузі; } \\
\text { - здатність до адапта- } \\
\text { ції новітніх творчих } \\
\text { досягнень; } \\
\text { - здатність до вияв- } \\
\text { лення протиріч }\end{array}$ \\
\hline II & $\begin{array}{l}\text { - розкриття творчого } \\
\text { інтересу студен- } \\
\text { тів-медиків; } \\
\text { - індивідуалізація } \\
\text { творчо-професійної } \\
\text { діяльності студентів; } \\
\text { - формування чіткої } \\
\text { індивідуальної } \\
\text { творчо-пізнавальної } \\
\text { позиції в досліджу- } \\
\text { ваній галузі }\end{array}$ & $\begin{array}{l}\text { - впровадження поза- } \\
\text { навчальних додатко- } \\
\text { вих занять } 3 \text { цікавої } \\
\text { для кожного студента } \\
\text { галузі медичної термі- } \\
\text { нології; } \\
\text { - проведення нау- } \\
\text { ково-практичних } \\
\text { семінарів з медичної } \\
\text { термінології, з яких } \\
\text { студенти представляли } \\
\text { результати індивідуаль- } \\
\text { них творчих досліджень }\end{array}$ & $\begin{array}{l}\text { - здатність до творчої } \\
\text { розробки виявленого } \\
\text { протиріччя; } \\
\text { - твердість, підпри- } \\
\text { ємливість у реалізації } \\
\text { творчих рішень; } \\
\text { - прагнення до } \\
\text { істинності творчого } \\
\text { судження }\end{array}$ \\
\hline
\end{tabular}


The development of creative and pedagogical aspects in the process of...

Закінчення таблиці 3

\begin{tabular}{|c|c|c|c|}
\hline 1 & 2 & 3 & 4 \\
\hline III & $\begin{array}{l}\text { - розвиток у сту- } \\
\text { дентів початкової } \\
\text { творчо-професійної } \\
\text { позиції; } \\
\text { - організація } \\
\text { індивідуального } \\
\text { самостійного науко- } \\
\text { во-творчого пошуку } \\
\text { студента }\end{array}$ & $\begin{array}{l}\text { - індивідуальний само- } \\
\text { стійний науковий твор- } \\
\text { чий пошук студента; } \\
\text { - анонсування самим } \\
\text { студентом особистих } \\
\text { творчих результатів; } \\
\text { - доопрацювання } \\
\text { деталей; } \\
\text { - наполегливий твор- } \\
\text { чий пошук найбільш } \\
\text { раціональних способів } \\
\text { вирішення творчих } \\
\text { завдань }\end{array}$ & $\begin{array}{l}\text { - здатність аналізу- } \\
\text { вати особисті творчі } \\
\text { досягнення; } \\
\text { - здатність доопрацю- } \\
\text { вати деталі; } \\
\text { - творча гнучкість }\end{array}$ \\
\hline
\end{tabular}

Результатом проведеної дослідно-експериментальної роботи стало поетапне формування у студентів експериментальної групи творчо-професійної готовності, що було досягнуто в процесі становлення і розвитку їх особистого креативного дослідницького потенціалу.

\section{5. Розвиток творчо-особистісних якостей}

Розвиток особистого креативного дослідницького потенціалу студентів здійснювався при формуванні у них творчо-особистісних якостей: висока професійна грамотність в обраній сфері медичної науки; прагнення до вивчення новітніх творчих досягнень; вміння аналізувати новітні творчі досягнення; здатність до виявлення протиріч; здатність до творчої розробки виявленого протиріччя; твердість, підприємливість у реалізації творчих рішень; прагнення до істинності творчого судження; здатність до аналізу особистих творчих досягнень; вміння доопрацьовувати деталі; творча гнучкість як здатність переходити від одного аспекту до іншого, від однієї гіпотези до більш досконалої.

У ході нашої дослідно-експериментальної роботи була проведена діагностика рівня розвитку у студентів-медиків експериментальної групи творчо-особистісних якостей на початку і після завершення експерименту.

Показники рівня розвитку у студентів творчо-особистісних якостей представлені в таблиці 4: 
Kichula Maria, Savaryn Tetyana

\begin{tabular}{|l|c|c|}
\hline \multicolumn{3}{|c|}{} \\
\begin{tabular}{|} 
Творчо-особистісні якості, які формують \\
особистий дослідний потенціал студентів ЕГ
\end{tabular} & $\begin{array}{c}\text { На початку } \\
\text { експерименту }\end{array}$ & $\begin{array}{c}\text { Пабля } \\
\text { завершення } \\
\text { експерименту }\end{array}$ \\
\hline $\begin{array}{l}\text { висока професійна грамотність в обраній } \\
\text { сфері медичної науки }\end{array}$ & $32 \%$ & $78 \%$ \\
\hline прагнення до вивчення новітніх досягнень & $31 \%$ & $74 \%$ \\
\hline здатність до аналізу новітніх творчих досягнень & $15 \%$ & $61 \%$ \\
\hline здатність до виявлення протиріч & $13 \%$ & $60 \%$ \\
\hline $\begin{array}{l}\text { здатність до творчої розробки виявленого } \\
\text { протиріччя }\end{array}$ & $12 \%$ & $58 \%$ \\
\hline $\begin{array}{l}\text { твердість, підприємливість у реалізації твор- } \\
\text { чих рішень }\end{array}$ & $11 \%$ & $53 \%$ \\
\hline прагнення до істинності творчого судження & $9 \%$ & $51 \%$ \\
\hline $\begin{array}{l}\text { здатність до аналізу особистих творчих } \\
\text { досягнень }\end{array}$ & $15 \%$ & $53 \%$ \\
\hline здатність доопрацьовувати деталі & $8 \%$ & $58 \%$ \\
\hline творча гнучкість & $6 \%$ & $52 \%$ \\
\hline
\end{tabular}

Як видно з таблиці, у результаті проведеної нами дослідно-експериментальної роботи у студентів експериментальної групи спостерігається значне підвищення рівня розвитку творчо-особистісних якостей, які формують творчий дослідницький потенціал.

У контрольній групі тільки деякі студенти проявили інтерес до дослідження галузі медичної термінології, які займалися написанням рефератів з певної теми. У результаті даного виду роботи у деяких студентів контрольної групи були розвинені такі творчо-особистісні якості: професійна грамотність у ділянці наукової медичної термінології, прагнення до вивчення новітніх творчих досягнень у галузі наукової медичної термінології; здатність до аналізу новітніх творчих досягнень; іноді - здатність до виявлення протиріч. Однак розвиток тільки цих якостей виявилася недостатнім для формування особистого дослідницького потенціалу.

Таким чином, у результаті дослідно-експериментальної роботи нами було доведено, що запропонований нами підхід до розвитку освіти студентів-медиків з урахуванням творчо-педагогічного аспекту сприяє ефективному розвитку індивідуальності майбутніх фахівців у сфері науково-медичних досліджень, а також становленню таких особистісних якостей, як здатність до самоосвіти, саморозвитку та самов- 
досконалення, формування творчих навичок та вмінь при реалізації індивідуальних досліджень і успішне застосування отриманих знань на практиці.

Результати третього діагностичного зрізу свідчать про значне розширення творчого інтересу студентів-медиків експериментальної групи, про формування творчої особистості даних студентів, про достатню готовність студентів-медиків експериментальної групи до самостійної професійної творчої діяльності, про формування у них чіткої творчо-пізнавальної позиції в дослідженні ділянки медичної термінології.

Проведена дослідно-експериментальна робота показує, що в експериментальній групі простежується зростання творчих зацікавлень у науково-дослідній роботі студентів-медиків у порівнянні з результатом, показаним у контрольній групі. Отримані дані свідчать про ефективність розробленого підходу до модернізації освітнього процесу у вищій медичній школі з урахуванням творчо-педагогічного аспекту.

Як показали наведені вище результати, у ході пошуково-творчого етапу дослідження істотно зросли готовність студентів експериментальної групи вирішувати професійні творчі завдання і можливість ефективно застосовувати медико-професійні знання, отримані в результаті індивідуальних творчих досліджень.

У результаті третього діагностичного зрізу були отримані дані для порівняльного аналізу показників творчо-професійної готовності студентів-медиків контрольної і експериментальної груп до початку і після закінчення експерименту.

Для отримання більш докладних результатів проведеного експерименту нами було вивчено розподіл професійно-творчих потреб серед студентів-медиків контрольної і експериментальної груп, представлений у таблиці 5.

Аналіз отриманих даних, представлених у таблиці, показує, що внаслідок проведеної нами програми формування творчо-професійної готовності у студентів-медиків експериментальної групи значно зросли професійно-творчі потреби в порівнянні зі студентами контрольної групи, де такі показники помітно знизилися. Отримані дані дозволяють нам стверджувати, що проведена нами дослідна робота в експериментальній групі студентів-медиків істотно підвищила рівень ïх творчих зацікавлень у предметі, а також сприяла набуттю студен- 
Таблиця 5

Розподіл професійно-творчих потреб серед студентів-медиків контрольної і експериментальної груп (середні значення в балах)

\begin{tabular}{|c|c|c|c|c|}
\hline \multirow{3}{*}{$\begin{array}{l}\text { Професійно-творчі потреби } \\
\text { студентів-медиків }\end{array}$} & \multicolumn{4}{|c|}{ ГРУПИ } \\
\hline & \multicolumn{2}{|c|}{ Контрольна } & \multicolumn{2}{|c|}{ Експериментальна } \\
\hline & початок & кінець & початок & кінець \\
\hline $\begin{array}{l}\text { Потреби творчого самовираження і } \\
\text { творчої самореалізації }\end{array}$ & 8,2 & 8,4 & 7,7 & 9,6 \\
\hline Потреби подолання «творчої скутості» & 22 & 19 & 23,9 & 25,6 \\
\hline $\begin{array}{l}\text { Потреби адаптації до індивідуальної } \\
\text { професійно-творчої діяльності }\end{array}$ & 24,5 & 21,5 & 12,6 & 24,5 \\
\hline $\begin{array}{l}\text { Потреби формування індивідуальної } \\
\text { чіткої творчо-пізнавальної позиції }\end{array}$ & 20,7 & 7,4 & 9,7 & 25,6 \\
\hline
\end{tabular}

тами необхідних творчих навичок для подальшої роботи в інших ділянках медичної науки.

Таким чином, у результаті дослідно-експериментальної роботи нами було доведено, що запропонований нами підхід до становлення і розвитку освіти студентів-медиків з урахуванням творчо-педагогічного аспекту сприяє ефективному розвитку та індивідуальності майбутніх фахівців у сфері науково-медичних досліджень; а також становленню таких особистісних якостей, які сприяють до самоосвіти, саморозвитку та самовдосконалення в системі креативності; формування творчих навичок та вмінь при реалізації індивідуальних досліджень і успішного застосування отриманих знань на практиці.

\section{6. Аналіз результатів експериментально-дослідної роботи}

Стрімкий ріст значимості творчої і культурно-освітньої функції особисто-орієнтованої освіти студентів-медиків обумовило розгляд нами професійно-творчої підготовки майбутнього спеціаліста як безперервної інтеграційної системи, напрямленої на особистісний ріст студента, розвиток його творчо-професійних здібностей, що є необхідними у майбутній медичній діяльності і формуванні вмінь творчого вибору професійних рішень, адекватних специфіці медичної діяльності.

У зв'язку з цим наше дослідження було спрямоване на становлення і розвиток основних творчих якостей студентів медичного вузу з ура- 
хуванням творчо-педагогічного аспекту, який потребує подальшого розвитку, що сприятиме формуванню професійної творчої діяльності: творче усвідомлення відношення до індивідуальної креативної діяльності як необхідності видозмінення медичної професійної діяльності, творче формування власне студентом-медиком індивідуально-освітнього особистісного модусу, що враховує творчо-професійні потреби студента, його інтереси, переконання, творчо-оцінюючі критерії, творчо-пізнавальні прагнення до володіння новими творчо-професійними знаннями, бажання теоретичного і практичного підтвердження індивідуальних поглядів.

У ході дослідження нами виявлено, що саме ці творчі якості $є$ одними із основних факторів творчо-професійної зрілості студента-медика до індивідуальної науково-медичної діяльності.

Діагностика рівнів творчо-професійної зрілості перед першим етапом була проведена завдяки навчального (першого) діагностичного зрізу. Даний метод показав низький рівень творчої зацікавленості і творчо-професійної зрілості студентів:

- низький рівень творчої зацікавленості студентів-медиків - 72 \%,

- середній рівень творчої зацікавленості студентів-медиків 17 \%,

- високий творчої зацікавленості студентів-медиків - 11 \%.

Під час проведення формуючого експерименту була сформульована інша мета освітньої діяльності в системі творчо-педагогічного аспекту: становлення творчо-особистісної спрямованості в професійній роботі майбутніх медиків, формування творчої особистості студентів-медиків, здатність усвідомлювати творчий саморозвиток, виховання спеціаліста медичного профілю, який здатен до реалізації самостійно обраної системи творчих установок і цінностей.

Відтак для реалізації завдань експериментально-дослідної роботи у ДВНЗ «Тернопільський державний медичний університет імені I.Я. Горбачевського МОЗ України» нами було розроблену програму, що розрахована на кілька років іiі реалізації. У програмі передбачені такі завдання як: розробити методичну модель процесу формування спрямованості у становленні та розвитку особисті у ході навчальної діяльності студента-медика, у відповідності до розроблених і теоретично обгрунтованих нами підходів до модернізації освітнього процесу у вищих медичних закладах з урахування творчо-педагогічного аспекту. 


\section{7. Результати першого етапу експерименту}

Експеримент був проведений як на рівні загального вдосконалення навчально-виховного процесу із врахуванням творчо-педагогічного аспекту, так і на рівні індивідуальної навчально-виховної роботи зі студентами, типовими представниками різних рівнів творчої зрілості до професійно-медичної діяльності.

Робота включала три етапи :

1.Перший - осінній семестр, впродовж якого було вирішено такі завдання:

- активізація мотивів творчо-професійної діяльності студентів-медиків експериментальної групи;

- поглиблення уявлення студентів про предмет, що вивчається;

- формування творчої особистості студента-медика, яка усвідомлює необхідність творчої діяльності.

У комплексі творчо-педагогічних впливів, спрямованих на формування творчої зрілості студентів-медиків до професійної діяльності, запроваджено цикл семінарів з проблеми-творчо-професійної зрілості. При цьому, не порушуючи мети семінарів, порушувалися питання про розкриття змісту, структури творчої зрілості, шляхи і умови іï формування, інформувалося студентів експериментальної групи про методи формування в собі творчих якостей, що входять до структури даного виду творчо-професійної зрілості.

Роботу було розпочато із знайомства зі стандартною системою категорій, що вживаються при визначенні творчо-професійної зрілості. Це дозволило студентам експериментальної групи правильно виявити ознаки творчо-професійної зрілості, на основі цього виробляти систему спеціальних понять, за допомогою яких студенти аналізували феномен креативної зрілості як і у своїй поведінці, такі в поведінці інших людей.

На подальших семінарах проводилася творчо-педагогічне тренування по усвідомленню і максимальному використанню визначених категорій. Особливо ефективними в цьому плані були заняття із вивчення конкретних прикладів наукової творчо-професійної діяльності відомих спеціалістів, а також прикладів із власного досвіду студентів-медиків і аналіз в системі категорій, що описують творчо-професійну зрілість майбутніх лікарів.

На першому етапі експерименту було активізовано процеси творчого навчання, що були відображені у даних другого діагностичного 
зрізу. Вони показали підвищення рівня креативної зацікавленості і творчо-професійної зрілості студентів-медиків експериментальної групи:

- низький рівень творчої зацікавленості студентів-медиків - 49\%

- середній рівень - $32 \%$

- високий рівень - $19 \%$.

На основі результатів другого (середнього) діагностичного зрізу було визначено завдання другого етапу експериментальної роботи:

- розвиток потреби вдосконалити творчо0професійні дослідження;

- формування творчо-управлінських якостей і можливостей студентів-медиків.

- створення ситуації реальної культуро-творчої відповідальності;

- індивідуалізація творчо-освітнього процесу студентів-медиків;

- адаптація студентів до індивідуальної творчо-професійної діяльності;

- розкриття і самостійна реалізація творчої цікавості майбутніх лікарів у сфері медичної термінології;

- формування індивідуальної чіткої творчо-пізнавальної позиції;

- становлення здатності до творчо-професійної самореалізації студентів-медиків;

- накопичення індивідуального досвіду творчо-професійної діяльності.

\section{8. Другий експериментальний етап}

Основним у ході другого експериментального етапу було поглиблення і розширення початої на першому етапі роботи зі становлення творчо-професійної зрілості студентів-медиків.

В основі організації другого навчально-виховного етапу в системі творчо-професійної аспекту було керівництво мотивами творчо-професійної діяльності студентів. Пріоритетним був спосіб творчо-педагогічного впливу, що базується на спеціально організованій креативній спрямованості студентських наукових досліджень. Відтак важливим завданням організації навчального виховної роботи було формування індивідуальної творчо-професійної мотивації.

Враховуючи дане завдання, до програми експерименту другого етапу було додано комплекс таких видів робіт:

- проведення додаткових позаурочних занять із тем, що є цікавими для студентів-медиків у сфері медичної термінології.

- науково-практичні семінари із медичної термінології, на яких студенти експериментальної групи представляли результати інди- 
відуальних творчих досліджень в системі-творчо-педагогічного аспекту.

Невід'ємною частиною вказаного виду занять було введення професійних ситуацій, що вимагали творчого вибору. При цьому практично реалізовувалися дві мети: розвиток творчо-професійної усвідомленості і вироблення творчих навиків професійного вирішення медичних завдань, вміння аналізувати і оцінювати свої креативні дії в професійній ситуації, підвищення творчо-професійної системи знань як необхідної умови становлення і розвитку навчання студентів-медиків.

\section{9. Третій етап експериментального дослідження}

Третій етап експериментального дослідження був присвячений розвитку у студентів-медиків експериментальної групи початкової творчо-професійної позиції, що мало місце в ході індивідуального самостійного наукового творчого пошуку студента - суб'єкта творчості; у аналізі власних творчих результатів, доопрацюванні деталей, наполегливому творчому пошуку раціональних способів вирішення творчих завдань.

На цьому етапі відбулося становлення таких творчо-педагогічних якостей, як можливість аналізувати власні творчі досягнення, здатність доопрацьовувати деталі, творча пластичність як здібність переходити від одного аспекту завдань до іншого, від однієї гіпотези до іншої - більш досконалої.

На прикінцевому етапі навчання в системі творчо-педагогічного аспекту, після проходження програми формування творчо-педагогічної зрілості студентів-медиків, проведено третій діагностичний зріз, що мав на меті оцінити ефективність розробленої програми. Дані, що отримані в результаті третього (завершального) діагностичного зрізу, свідчать про те, що рівень креативної зацікавленості і зрілості студентів-медиків значно виріс: низький рівень - 9\%; середній рівень - 29\%; високий рівень $-62 \%$.

Важливо відзначити, що процес формування креативної зрілості не завершений, у зв'язку з специфікою підготовки майбутніх лікарів, в основі якої є постійні творчі видозміни і вдосконалення. Таким чином, завершення нашого формуючого експерименту до кінця третього етапу не сприяв закінченню становлення творчо-професійної зрілості студентів-медиків. А етап консолідації компонентів творчо-професійної зрілості буде продовжуватися впродовж усього життя і професійної медичної діяльності майбутнього лікаря. Проте основи майбутньої 
творчо-професійної діяльності студентів-медиків експериментальної групи закладені вже в університеті.

\section{0. Висновки}

У зв'язку з цим, можна зробити висновок про те, що такі фактори як своєчасна діагностика і корекція рівнів творчо-професійної зрілості, інтеграція теорії і практики креативної підготовки, виховання культуро творчої активності, моделювання у навчальному процесі творчих ситуацій, що вимагають від студентів медичного вишу активних творчо-професійних рішень, поступове формування творчо-професійної зрілості, підвищують їх творчу зацікавленість до професійної діяльності і задоволеність отриманими результатами.

Таким чином експериментальна робота показала необхідність і цілеспрямованість впровадження принципів творчо-педагогічного аспекту у становлення і розвиток навчання студентів-медиків, для подальшого формування майбутніх високопрофесійних спеціалістів медичного профілю.

\section{Список літератури:}

1. Кыверялг А. А. Методы исследования в профессиональной педагогике / А. А. Кыверялг. - Таллин: Валгус, 1980. - 334 с.

2. Brophy J. Motywowanie uczniów do nauki / J. Brophy. - Warszawa: Wydawnictwo Naukowe PWN, 2002. - 278 s.

3. Ekiert-Oldroyd D. Twórcze rozwiązywanie problemów - model i jego zastosowanie w praktyce edukacyjnej / D. Ekiert-Oldroyd [W:] St. Popek (red.) Twórczość w teorii i praktyce. - Lublin: Wydawnictwo UMCS, 2004. - S. 295-302.

4. Guilford J.P. Creativity : Yesterday, today, and tomorrow / J. P. Guilford // Journal of Creative Behavior. - 1967. - No 1. - P. 3-14.

5. Nęcka E. Trening twórczości / E. Nęcka. - Olsztyn : Polskie Towarzystwo Psychologiczne Pracownia Wydawnicza, 1992. - 178 s.

\section{References:}

1. Kyverialh, A. A. (1980) Metody yssledovanyia v professyonalnoi pedahohyke [Methods of research in professional pedagogy]. Tallyn: Valhus (in Russian).

2. Brophy, J. (2002) Motywowanie uczniów do nauki. Warszawa: Wydawnictwo Naukowe PWN.

3. Ekiert-Oldroyd D. (2004) Twórcze rozwiąywanie problemów - model $i$ jego zastosowanie w praktyce edukacyjnej. [W:] Popek, St. (red.) Twórczość w teorii i praktyce. Lublin : Wydawnictwo UMCS: ss. 295-302

4. Guilford, J.P. (1967) Creativity: Yesterday, today, and tomorrow. The Journal of Creative Behavior, 1, 3 - 14. doi:10.1002/j.2162-6057.1967.tb00002.x

5. Nęcka E. (1992) Trening twórczości. Olsztyn : Polskie Towarzystwo Psychologiczne Pracownia Wydawnicza. 